\title{
Circulation Service Desk Operations: Costing and Management Data
}

\author{
Pat Weaver-Meyers, Duncan Aldrich, \\ and Robert A. Seal
}

The University of Oklahoma Libraries' Department of Access Services conducted a cost study of circulation service-desk operations. Service-desk tasks were flowcharted to identify important components. Work sampling observations were used to determine the percentage of staff time occupied in particular tasks. Observations were made at random by uninvolved observers. Using the percentages obtained, pay rates, indirect costs, and overhead, total costs were computed on a task-by-task basis. Also, several tabulations of the same data were used to identify idle time and peak-use periods. This information then served as a basis for reorganization of work assignments and revision of staff scheduling. Improved efficiency and service, without any staffing increase, were the result.

$\mathrm{n}$ academic library public service desk is typically the scene of a variety of activities involving both patron interaction and processing. Whether circulation, reference, or some other function, these service points must be staffed at all times the library is open. The cost of each activity and the amount of time spent on each are of interest since such analyses can provide managers with information for planning and change, with an ultimate goal of improving service and the efficiency of operations. The circulation department, with a high degree of routine, repetitive work, and a variety of tasks, is ideally suited to work sampling analyses. The present study attempts to determine the cost of operating the main library circulation desk at the University of Oklahoma, focusing in particular on determining the costs of each major task and the proportion of time spent on each by various levels of staff.

This paper begins with a brief review of the literature, examining costing and other quantitative methods that have been previously used to analyze circulation operations. Following is a description of the methodology used in the present study along with an analysis of the results. The departmental reorganization that resulted from the cost study is discussed.

\section{LITERATURE REVIEW}

As a preface to the discussion of the present cost study, it would be useful to review important efficiency and cost studies done previously in order to place our study in context with other research. This should also provide a brief comparative review for those interested in duplicating the study for their own purposes.

As early as the mid-1960s, basic work measurement was being applied to circulation operations. ${ }^{1}$ Kozumplik called for the use of quantitative methods and applied them to standards of production and goal setting. He cited an unexpected esprit de corps associated with the study of production levels. In his 1970 review of quantitative management, Fred Heinritz felt that librarians, mostly with backgrounds

Pat Weaver-Meyers is access services department head, Duncan Aldrich is circulation supervisor, and Robert A. Seal is director of library public services at University of Oklahoma Libraries, Norman, Oklahoma 73019. 
in the humanities, greatly underutilized the potential of these measures in all aspects of library operations. ${ }^{2}$

Top-down costing, a breakdown of cost by department from library-wide budgets, has been used for years by administrators in budget justification. A well-known example is the Stanford study first completed in $1965 .{ }^{3}$ Cost-benefit analysis is another type of costing sometimes applied to circulation. ${ }^{4}$ It is a method of allocating resources most efficiently when numerous departments are competing for the same budget dollar. This analysis may require the use of sophisticated techniques.

Budget justification appears to have been a major motivation in the trend to use more specific costing measures in circulation during the $1970 \mathrm{~s}$. When turn-key and in-house automation of circulation gained in popularity, librarians attempted to justify the purchase of such systems through costing. Some of the first cost studies were comparisons of manual versus automated systems via time studies that provided specific task information. ${ }^{5}$ These studies generally found automation to be more expensive than manual systems $-a$ fact that forced administrators to pursue a more sophisticated rationale, such as efficiency, effectiveness, and service quality. ${ }^{6}$

A new trend toward modeling of circulation systems has become popular in the last five to ten years. Manpower needs ${ }^{7}$ and loan dynamics ${ }^{8}$ are just two of several topics for which models have been proposed. Throughout the development of these strategies for examining circulation operations, public libraries have continued to apply costing analysis. One unusual application contrasts types of patrons and determines which patron should bear the burden of circulation costs. ${ }^{9}$ Another study compares loss rates with the elimination of overdue fines and the cost effectiveness of such a policy in conjunction with paperback versus hardback use. ${ }^{10}$

It is also important to note that quantitative measures have been applied to a number of other circulation concerns not involving costs, but relating instead to the effectiveness of the circulation depart- ment. Specifically, optimal loan periods and their effect on book availability have received much attention. ${ }^{11}$

Even though much has been done to apply costing and other quantitative methods to circulation, a study by David Kohl on the use of and need for management data by circulation professionals indicated that such analyses are deemed important, but data provided by others is considered more important than self-generated data. ${ }^{12}$ Kohl further points out that such findings may be the result of lack of training in data analysis skills-the same conclusion reached by Heinritz in 1970 ! This widespread lack of self-study is reinforced by the fact that information on what it costs another library of similar size and makeup to charge a book is not readily available. Although exchange of in-house reports indicates some circulation cost data is available, ${ }^{13}$ it does not appear that circulation services costs are included in such reports, except in the broad context. Task-specific data on circulation is scarce.

Since public service activity can be varied and not routine, quantitative measurement is more difficult than in technical services. Stella Mosborg's application of random observation to circulation activities is one of the first studies in which staff time spent on specific tasks was determined in this manner. ${ }^{14}$ Previously, some time studies were done, but this type of study does not account for a variation in the type of staff performing the procedure- a factor that varies in the public service setting. By random observation, Mosborg was able to show how much time different staff contributed to the same task. The same technique was used in the present study, with added computations that provided specific costing per task. It is this specificity that allows close scrutiny of department operations. Such examination is the only means of providing a public service manager with data so specific that a single task or procedure might be targeted for manipulation or elimination for reasons of efficiency. Not only can the task itself be broken down, but also the amount of time expended on that task by staff members with widely divergent salaries. 
Finally, random sampling is a very simple methodology that is subtle enough not to affect service. An observer can easily monitor service, unseen or rarely noticed by staff. Handily, observation also provides additional useful management data for scheduling and work flow changes that can be used for practical, actionoriented solutions to efficiency shortfalls. Therefore, both the administrator and the middle manager can benefit from the data. A brief description of the circulation desk situation and the calculations used in the study follow.

\section{BACKGROUND}

The University of Oklahoma's main library circulation desk is open for service approximately ninety hours per week. Student assistants make up the regularly scheduled staff. Backup staffing and supervisory support are provided by fulltime staff and faculty. (Hereafter, "staff" refers to full-time non-student employees.) Four full-time staff members perform stack maintenance and circulation supervision, billing, and reserve duties. These same staff, along with the department head, provide backup to student workers until 10:00 p.m. The main library collection primarily addresses social sciences, business, humanities, and biological sciences, while "hard" sciences and fine arts are served by branch libraries on campus. Therefore, the borrowing population is comprised of faculty, staff, students, and courtesy borrowers with these fields of interest. Circulation for the 1982-83 fiscal year was about 150,000 . Reserve materials are also circulated from the desk and it is a pickup point for interlibrary loan. In addition, the desk is the patron consultation area for billing complaints and, due to its location, provides substantial directional information to users. Circulation of monographs and reserve materials is automated on the DataPhase ALIS II system, while bound periodicals circulate manually.

\section{METHODOLOGY}

Initially several methodologies for costing services were reviewed. Although a time study was found to be a proven methodology, ${ }^{15}$ it was not adopted. Rather, work sampling was selected as a previously successful method that appeared less invasive of normal work flow than a time study. Work sampling has been successfully used in a number of library studies of work analysis ${ }^{16}$ and has proven useful in the costing of some procedures such as interlibrary loan. ${ }^{17}$

Work sampling methodology made it simple to limit the study to observation of service desk personnel and to catch unscheduled backup personnel in the act of providing services. This also made it easy to target circulation desk operations, excluding back-office functions that support the front desk. Additionally, there was interest in determining the cost of specific tasks such as charging or discharging an item. In work sampling, specific tasks and personnel can be readily observed and tallied, easily providing the basic information necessary for costing particular activities.

In preparation, all the routines normally performed at the circulation desk were flowcharted. The flowchart made it easy to identify those components that were of major interest: charge, renewal, discharge, online inquiry, etc. These tasks were then divided in component parts to allow scrutiny of the efficiency of procedures for possible future streamlining. Some additional categories were identified, but not broken down into steps. All the identified tasks were then incorporated into a recording chart used by observers. It should be noted here that the simple creation of the recording chart can be a valuable exercise. The selfexamination required may reveal problems or bottlenecks before the study even begins. Figure 1 is an example of the chart used to record observations.

In recording observations, codes were used to specify the type of worker engaged in providing the service. Although the desk is primarily manned by student workers, a fair proportion of staff time is spent assisting student employees when business picks up or when problems demand supervisory input. One of the goals of the study was to find out how much time was spent by staff in this backup role. 


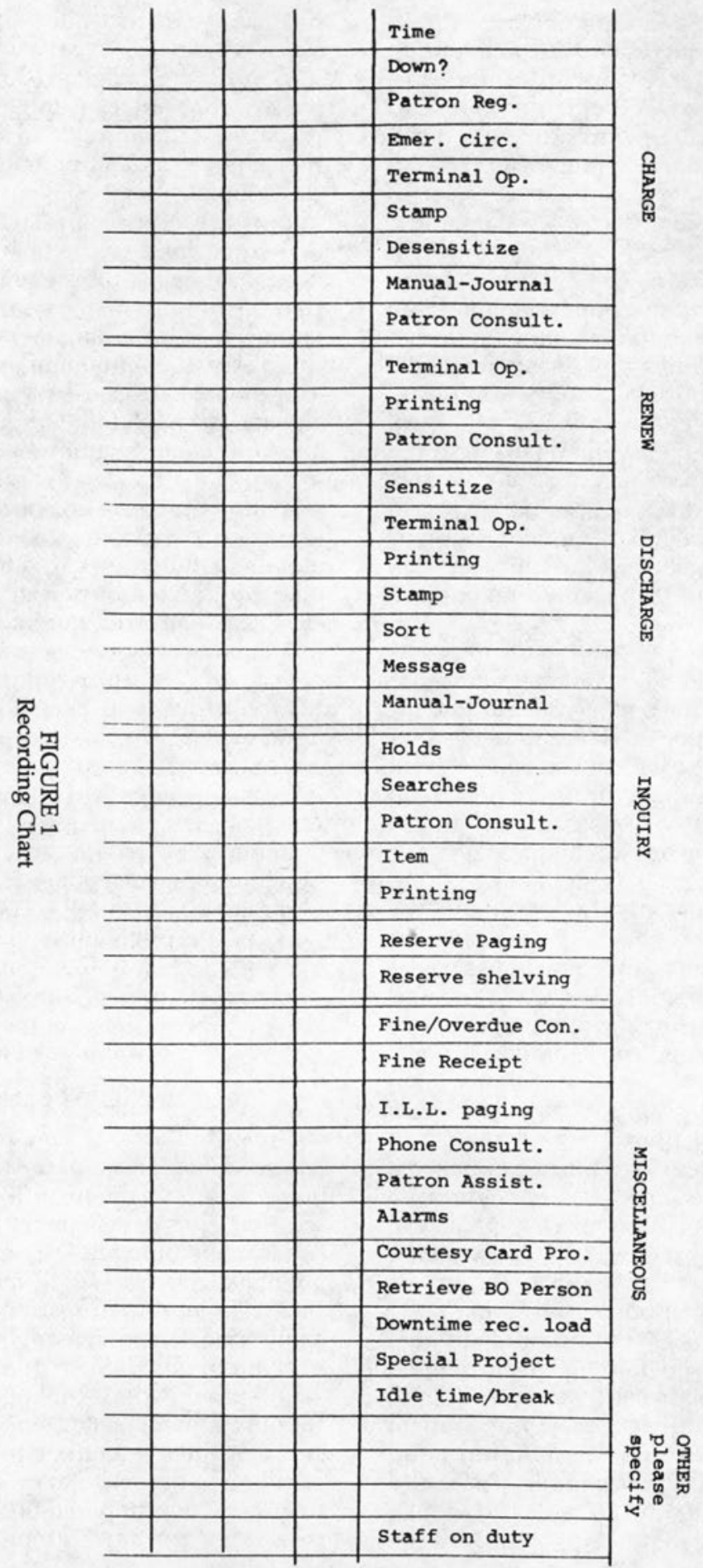


Further, considering the higher cost of staff service, compared to that of student assistants, it was felt that the cost figures would be more accurate if staff time was calculated. Also, management was interested in the direct-service time requirement and how that compared to the proportion of time spent by staff in back-office duties. A comparison of the time each staff member spends at the desk relative to the work for which they are normally responsible can give a manager specific information about unstructured work time. If the billing supervisor, for example, spends 50 percent of her time interacting with patrons, the manager might conclude that she needed additional clerical assistance for back-office paperwork.

Most observations were made by staff or student supervisors. Before the study began, the methodology was discussed at a weekly staff meeting, and all workers were informed of the project's intent. A special effort was made to inform everyone that only worker types were going to be recorded, not individual names. It was hoped that this explanation, along with assurances that some idle time was expected, would prevent workers from deliberately improving their efficiency for the duration of the study.

To assist in the sampling process, an inexpensive digital alarm watch was purchased and attached to a clipboard with the observation charts. Using a random timetable, ${ }^{18}$ each projected observation time was recorded on the charts each day. At the beginning of each day, the first observer would set the watch alarm to ring for the first observation time. When the alarm went off, the observer would proceed to the circulation-desk area, record the activities of all the staff present at that instant, and reset the alarm for the next observation time listed. While recording, the observer would pay special attention to the student work schedule. Those indi-viduals actually scheduled for desk service would be noted. If an individual was taking a break or was otherwise absent at that moment, he or she would be recorded in the idle-time category. Since the concern was solely with what occurred at the front desk, staff not regularly scheduled were recorded only if they were involved in front-desk activity when the alarm sounded. The observations would continue throughout each day in the same manner until closing. During lunch breaks or in the evening, the clipboard would be passed on to another observer familiar with the procedure.

The study was conducted in October, specifically because it was a moderately busy time of year. About fifty samplings were made each day, and the study period encompassed nine days including one weekend. During any one observation, from two to five workers could be engaged in front-desk service. In all, 1,267 observations were made.

A test sample of one day's observations was conducted prior to the actual sampling. This test provided a base from which estimates could be made of the percentage of time workers were involved in any one task. Also, any shortcomings in the recording chart could be discovered and corrected before the actual sampling began. The percentages revealed were then used to set the sample size at 1,290, using a table designed for that purpose. ${ }^{19}$ This sample size has an accuracy between 2.5 percent and 3.0 percent with a 95 percent confidence level.

\section{RESULTS}

The data gathered from the observations were analyzed using SAS (Statistical Analysis System) frequency procedures. In SAS, frequency procedures tally every variable loaded by category. This provides the frequency with which any particular procedure was observed. Coupled with the other notations made on the recording chart (variables), SAS can manipulate the data to produce cross-tabulations. Each observation included the following variables: staff type, procedure, time of day, day of the week.

Since each observation included four variables, a variety of tables could be produced. For example, a frequency table of "staff type/procedure" was used to compute the particulars of costing by task. "Procedure/time of day" and "procedure/day of the week" tables were used by the circulation supervisor to adjust 
scheduling so that coverage during the busiest times of the day was adequate. Of course, several other permutations are possible. Clearly, one random observation study that includes the recording of several characteristics can provide data for numerous management needs.

The table of "staff type/procedure" (see table 1) is a consolidated version that collapses forty-one separate tasks into ten procedure categories. As mentioned earlier, several of the major procedures were broken down into component tasks for indepth analysis of the work flow. For the purposes of costing, though, only the ten major procedures were examined.

This particular table, which displays nine of the twelve staff types, allows examination of the time contributed by support staff and faculty. Since no faculty or full-time staff are formally scheduled at the desk, the amount of time they contributed to desk operations was not clearly evident until the sampling was complete. In table 1, under the column headed Circ. Super., one can see that the circulation supervisor contributed 2.14 percent of all the staffing at the desk. Since the supervisor works a forty-hour week and the observation period spanned seven weekdays and one weekend, he could have worked a maximum of fifty-six hours at the front desk. From the table, two questions were answered:

1. How many of the possible fifty-six hours of the supervisor's time were spent assisting at the front desk?

2. How much did the circulation supervisor's salary rate contribute to the increased cost of providing service on a taskby-task basis?

In order to compute the amount of the supervisor's time spent at the desk, the following formula was used:

$$
\mathrm{S}=(\mathrm{N} / \mathrm{A}) \times \mathrm{H}
$$

$\mathrm{N}=$ Total number of observations of supervisor at the desk

$\mathrm{A}=$ Total number of times the observer answered the alarm

$\mathrm{H}=$ Number of hours desk was open during observation period

$S=$ Number of hours supervisor was at the desk
$27 / 375=.07 \times 118=8.26$ hours per nineday observation period

Dividing by 56 , the number of hours of supervisor time, gives $8.26 / 56=.15$, or 15 percent of the circulation supervisor's time is spent providing service at the front desk. Also, from table 1 it can be seen that 44.44 percent of his contribution at the desk is spent in miscellaneous activity. It appears that most of the supervisor's time is spent in other activities rather than providing charge/discharge services.

Considering the higher salary of the circulation supervisor, it is more costeffective if his time is spent in supervisory rather than in desk activity. It is less expensive to have that task performed by a student assistant. This concept is clearly illustrated by figure 2 , in which the direct labor cost per hour for the charge procedure has been computed. As shown, the percentage of time a particular staff type was observed in charge/renewal is multiplied by hourly salary (including fringe benefits) to obtain the cost per hour per type for all staff observed in that procedure. The final total then is $\$ 4.11$ per hour of direct labor costs associated with charge/renewal.

In this example, the student assistants, class 1 , contribute the greatest personpower to the procedures of charge/renewal. Student assistants, class 1 , make up 57.26 percent of the personpower devoted to this procedure. Consequently, direct labor costs for this procedure are relatively low, since this group is the lowest paid of all staff types.

Table 2 shows all the broad task categories and the cost per hour associated with each task. When the cost per hour, computed by the same procedure illustrated in figure 2, is multiplied by the percentage of staff time devoted to the procedure, the resulting overall service desk cost per hour is tabulated. This overall average of $\$ 4.18$ (see table 2) can then be compared to each individual cost per hour per task to determine which is the most expensive service to provide and which task contributes the most to the overall average expense. For example, charge/renewal accounts for $\$ 1.28$ of the overall average, 
TABLE 1

PROCEDURE BY SELECTED STAFF TYPE

\begin{tabular}{|c|c|c|c|c|c|c|c|c|c|}
\hline $\begin{array}{l}\text { Frequency } \\
\text { Percent } \\
\text { Row \% } \\
\text { Col \% } \\
\end{array}$ & $\begin{array}{l}\text { Dept. } \\
\text { Head }\end{array}$ & $\begin{array}{l}\text { Billing } \\
\text { Super. }\end{array}$ & $\begin{array}{l}\text { Circ. } \\
\text { Super. }\end{array}$ & $\begin{array}{l}\text { Security } \\
\text { Guard }\end{array}$ & $\begin{array}{l}\text { ted Staff Type } \\
\text { ILL } \\
\text { Student } 1\end{array}$ & $\begin{array}{l}\text { Computer } \\
\text { Operator }\end{array}$ & $\begin{array}{l}\text { ILL } \\
\text { Super. }\end{array}$ & $\begin{array}{l}\text { Reserve } \\
\text { Super. }\end{array}$ & $\begin{array}{l}\text { Stack } \\
\text { Main. } \\
\text { Super. }\end{array}$ \\
\hline \multicolumn{10}{|l|}{ Procedure } \\
\hline Billing & $\begin{array}{r}0 \\
0.00 \\
0.00 \\
0.00\end{array}$ & $\begin{array}{r}4 \\
0.32 \\
26.67 \\
28.57\end{array}$ & $\begin{array}{r}0 \\
0.00 \\
0.00 \\
0.00\end{array}$ & $\begin{array}{l}0 \\
0.00 \\
0.00 \\
0.00\end{array}$ & $\begin{array}{l}0 \\
0.00 \\
0.00 \\
0.00\end{array}$ & $\begin{array}{l}0 \\
0.00 \\
0.00 \\
0.00\end{array}$ & $\begin{array}{l}0 \\
0.00 \\
0.00 \\
0.00\end{array}$ & $\begin{array}{r}0 \\
0.00 \\
0.00 \\
0.00\end{array}$ & $\begin{array}{r}0 \\
0.00 \\
0.00 \\
0.00\end{array}$ \\
\hline Charge & $\begin{array}{r}2 \\
0.16 \\
0.51 \\
25.00\end{array}$ & $\begin{array}{r}1 \\
0.08 \\
0.25 \\
7.14\end{array}$ & $\begin{array}{r}5 \\
0.40 \\
1.27 \\
18.52\end{array}$ & $\begin{array}{r}16 \\
1.27 \\
4.06 \\
14.68\end{array}$ & $\begin{array}{r}0 \\
0.00 \\
0.00 \\
0.00\end{array}$ & $\begin{array}{r}0 \\
0.00 \\
0.00 \\
0.00\end{array}$ & $\begin{array}{r}1 \\
0.08 \\
0.25 \\
28.57\end{array}$ & $\begin{array}{r}4 \\
0.32 \\
0.25 \\
28.57\end{array}$ & $\begin{array}{r}2 \\
0.16 \\
0.51 \\
66.67\end{array}$ \\
\hline Discharge & $\begin{array}{r}0 \\
0.00 \\
0.00 \\
0.00\end{array}$ & $\begin{array}{l}0 \\
0.00 \\
0.00 \\
0.00\end{array}$ & $\begin{array}{r}2 \\
0.16 \\
1.40 \\
7.41\end{array}$ & $\begin{array}{l}1 \\
0.08 \\
0.70 \\
0.92\end{array}$ & $\begin{array}{l}0 \\
0.00 \\
0.00 \\
0.00\end{array}$ & $\begin{array}{l}0 \\
0.00 \\
0.00 \\
0.00\end{array}$ & $\begin{array}{r}0 \\
0.00 \\
0.00 \\
0.00\end{array}$ & $\begin{array}{r}0 \\
0.00 \\
0.00 \\
0.00\end{array}$ & $\begin{array}{r}0 \\
0.00 \\
0.00 \\
0.00\end{array}$ \\
\hline Idle Time & $\begin{array}{r}2 \\
0.16 \\
0.79 \\
25.00\end{array}$ & $\begin{array}{r}0 \\
0.00 \\
0.00 \\
0.00\end{array}$ & $\begin{array}{r}0 \\
0.00 \\
0.00 \\
0.00\end{array}$ & $\begin{array}{r}51 \\
4.03 \\
20.16 \\
46.79\end{array}$ & $\begin{array}{r}0 \\
0.00 \\
0.00 \\
0.00\end{array}$ & $\begin{array}{r}0 \\
0.00 \\
0.00 \\
0.00\end{array}$ & $\begin{array}{r}0 \\
0.00 \\
0.00 \\
0.00\end{array}$ & $\begin{array}{r}2 \\
0.16 \\
0.79 \\
14.29\end{array}$ & $\begin{array}{r}0 \\
0.00 \\
0.00 \\
0.00\end{array}$ \\
\hline ILL Paging & $\begin{array}{r}1 \\
0.08 \\
14.29 \\
12.50\end{array}$ & $\begin{array}{r}0 \\
0.00 \\
0.00 \\
0.00\end{array}$ & $\begin{array}{r}0 \\
0.00 \\
0.00 \\
0.00\end{array}$ & $\begin{array}{r}0 \\
0.00 \\
0.00 \\
0.00\end{array}$ & $\begin{array}{r}0 \\
0.00 \\
0.00 \\
0.00\end{array}$ & $\begin{array}{r}0 \\
0.00 \\
0.00 \\
0.00\end{array}$ & $\begin{array}{r}0 \\
0.00 \\
0.00 \\
0.00\end{array}$ & $\begin{array}{r}0 \\
0.00 \\
0.00 \\
0.00\end{array}$ & $\begin{array}{r}0 \\
0.00 \\
0.00 \\
0.00\end{array}$ \\
\hline Inquiry & $\begin{array}{r}0 \\
0.00 \\
0.00 \\
0.00\end{array}$ & $\begin{array}{r}4 \\
0.32 \\
6.25 \\
28.57\end{array}$ & $\begin{array}{r}2 \\
0.16 \\
3.13 \\
7.41\end{array}$ & $\begin{array}{r}4 \\
0.32 \\
6.25 \\
3.67\end{array}$ & $\begin{array}{r}0 \\
0.00 \\
0.00 \\
0.00\end{array}$ & $\begin{array}{r}0 \\
0.00 \\
0.00 \\
0.00\end{array}$ & $\begin{array}{r}1 \\
0.08 \\
1.56 \\
11.11\end{array}$ & $\begin{array}{r}4 \\
0.32 \\
6.25 \\
28.57\end{array}$ & $\begin{array}{r}0 \\
0.00 \\
0.00 \\
0.00\end{array}$ \\
\hline Misc. & $\begin{array}{r}1 \\
0.08 \\
0.57 \\
12.50 \\
\end{array}$ & $\begin{array}{r}2 \\
0.16 \\
1.15 \\
14.29\end{array}$ & $\begin{array}{r}12 \\
0.95 \\
6.90 \\
44.44\end{array}$ & $\begin{array}{r}7 \\
0.55 \\
4.02 \\
6.42\end{array}$ & $\begin{array}{r}0 \\
0.00 \\
0.00 \\
0.00 \\
\end{array}$ & $\begin{array}{r}0 \\
0.00 \\
0.00 \\
0.00 \\
\end{array}$ & $\begin{array}{r}1 \\
0.08 \\
0.57 \\
11.11 \\
\end{array}$ & $\begin{array}{r}0 \\
0.00 \\
0.00 \\
0.00 \\
\end{array}$ & $\begin{array}{r}0 \\
0.00 \\
0.00 \\
0.00 \\
\end{array}$ \\
\hline
\end{tabular}


while billing contributes only $\$ .05$ to the average even though billing service costs $\$ .38$ more per hour to provide.

Thus far, we have discussed only that portion of the data which pertain to direct labor costs. Obviously, a complete study includes indirect costs as well. Figure 3 is an itemized tally of the direct labor costs determined by the methods described and of the indirect costs attributable to the circulation desk. Multiplying the average salary per hour by the total hours worked at the desk per year produces a total direct labor cost. Since the hours worked at the desk in a year include both the scheduled student assistant time and the unscheduled full-time staff support time, the following computation was used to determine those hours:

397.55 hours worked at the desk in the nine-day observation period $=44.17$ hours per day.

$44.17 \times 350$ days open per year $=15,459.5$ hours worked at desk per year

However, the October observation time made the number of hours worked per day higher than the yearly average. The following adjustment was then applied:

4,025 hours open annually in 350 days = 11.5 average hours open per day throughout the year.

11.5/13.1 hours open per day during observation $=0.8779$

$0.8779 \times 15,459.5$ hours per year $=$ $13,571.9$ adjusted hours per year

The direct labor costs so computed were used to estimate the supervisory support within the department and to apportion the supplies and maintenance costs dedicated to the service desk operation. This subtotal was then used to find the percentage of the total library operating budget that the desk comprised. This 2.51 percent was then used in determining the portion of the university administration, computing services, etc., that needed to be considered. Operation and maintenance calculations were based on 1983-84 budget figures provided by the university's Office of Grants and Contracts. Student support services costs are not included in the indi- 
Using the table of procedure $\times$ staff, the following calculations were made to determine the direct cost/hr of a particular task.

\section{EXAMPLE CALCULATION OF COSTS FOR CHARGING/RENEWAL DIRECT LABOR}

Direct \% of Total Time

Devoted to Charging at

Circulation Desk by Staff Type

Dept. Head

.54

Billing Supervisor $\quad .27$

Circulation Super. $\quad 1.09$

Security Guard $\quad 4.36$

ILL Super. $\quad .27$

Reserve Super. $\quad 1.09$

Stack Main. Super. $\quad .54$

Student Asst. $1 \quad 57.26$

Student Asst. 2

Student Asst. 2 (Billing) $\quad 3.54$

Student Asst. 2 (Reserve) $\quad 3.81$

Student Asst. 2 (Searcher) 6.81

Student Asst. $3 \quad 16.89$

Student Asst. 3 (Billing) $\quad 2.72$

Student Asst. 3 (Reserve) $\quad .54$

$\$ / \mathrm{Hr}$.

Direct Labor

13.15

6.19

7.00

4.12

7.00

6.20

6.19

3.87

3.97

3.97

3.97

3.97

4.27

4.27

$\frac{4.27}{100.00 \%}$
Cost/Hr.

Type

.07

.02

.08

.18

.02

.07

.03

2.21

.01

.14

.15

.27

.72

.12

02

Total Direct Labor Cost $\$ 4.11 / \mathrm{hr}$

\section{EXAMPLE FOR CHARGE}

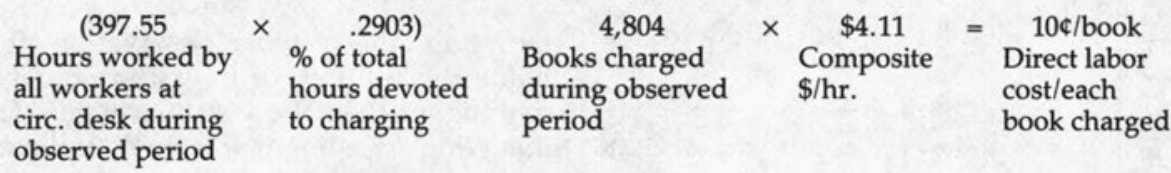

FIGURE 2

Cost/Hour/Task

TABLE 2

AVERAGE SALARY/HOUR/TASK

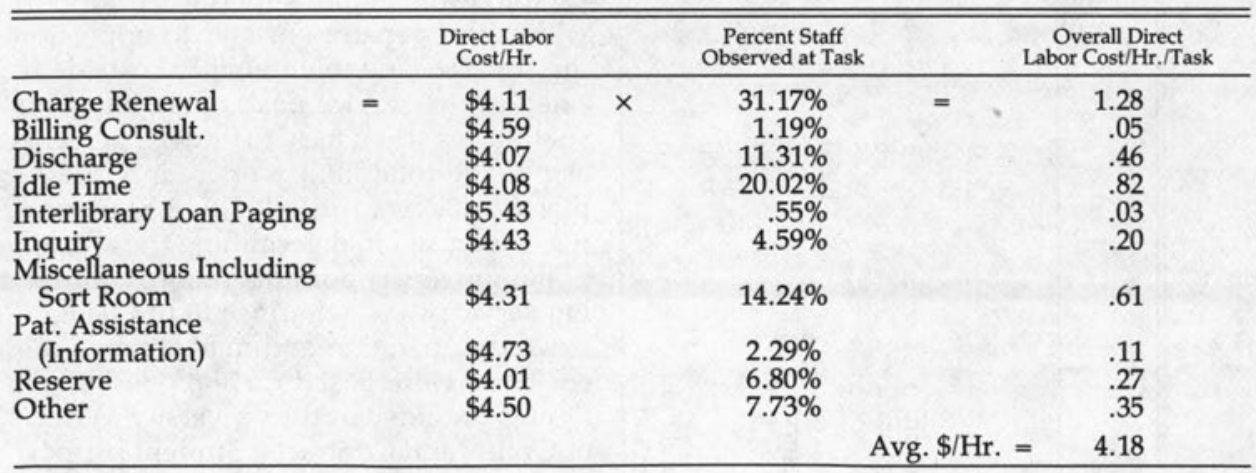


$\$ 56,730.54=$ Direct staff labor at circulation desk including fringe benefits based on the estimated total hours worked/year or Avg./hour salary $\$ 4.18 \times 13,571.9$ hours worked/year

$\$ 21,105.5=$ Intra-department supervision including $32 \%$ of dept. head's salary + $85 \%$ of circulation supervisor's salary.

$\$ 15,893.80=$ Circulation desk \% of total access services maintenance and supplies.

$\overline{\$ 93,729.84}$ Subtotal of circulation desk costs (used to determine circulation desk cost $\%$ of total library budget)

$\$ 19,873.42$ = Annualized costs (includes furniture, computer hardware, and computer software)

$\$ 14,987.16=$ Department administration (\% of Bizzell administration estimated to be concerned with circulation desk service)

$\$ 14,512.60=\$ 7.883 /$ sq. ft. $\times 1841$ sq. $\mathrm{ft} .=$ operations and maintenance

$\$ 1,875.34=$ General administration or $\$ 3,750,685 \times .02 \times .0251$

$\$ 1,043.86=$ Computer center support for library $\$ 41,588 \times .0251$

$\overline{\$ 146.022 .22}$ Grand total of 1983-84 operating costs for circulation desk service only

FIGURE 3

Total Cost Itemization: Circulation Desk Service

rect costs (associated with housing, food service, laundry, etc.) calculated for this study.

Table 3 incorporates both the direct and indirect costs to complete the task/task costing of the ten broad categories. Computations are summarized across the top of the table.

In summary, based on charge/renewal and discharge statistics during the observation period, average costs of $\$ .24$ per book for charge/renewal and $\$ .22$ per book for discharge were calculated. These figures exclude idle time, which is computed as a separate category. Complete circulation of an item includes overdue notices, billing, etc. That portion of expenses will be addressed in future department-wide studies.

\section{ANALYSIS}

Unless librarians are able to analyze cost data and use it in problem solving or in instituting change, the time and effort spent gathering such information will be wasted. Many library managers simply do not know how to use cost data to their advantage. Statistical packages such as SAS or SPSS (Statistical Package for the Social Sciences) can help in the analysis of data and do not require extensive program- ming knowledge. They can be run on nearly all campus mainframes from remote terminals. The availability of microcomputer statistical software is likewise making it easier for the librarian to manipulate and analyze cost and other data. The problem of circulation professionals being unfamiliar with data analysis, as pointed out by Kohl, is solved with these tools. ${ }^{20}$ Therefore, even the statistics neophyte can readily manipulate data. The information gathered is department-specific and can provide indicators for reorganization and comparison not found in the literature.

How can the cost data be used in a circulation or other library department? Three possible uses are described below:

1. to identify inefficient/ineffective procedures,

2. to provide levels of current performance against which later performance can be measured, and

3 . to assess the performance of any institution in light of research done elsewhere.

The third point should be done with restraint, however. According to Charles McClure, the internal organization and goals may differ drastically between institutions, making comparison difficult and 


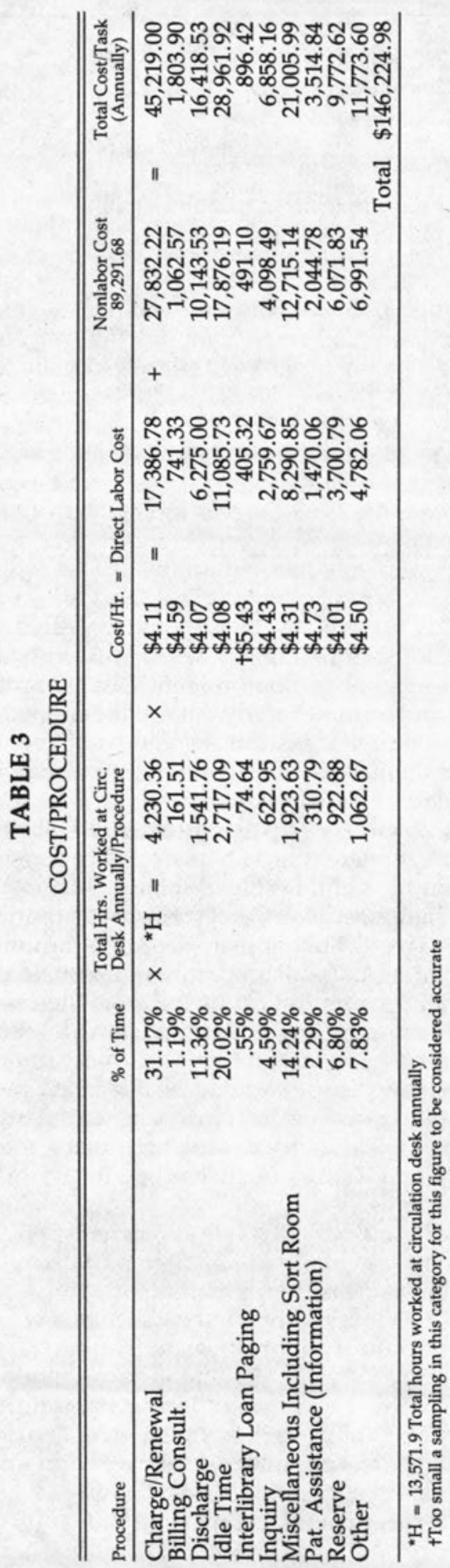

of questionable value. ${ }^{21}$ The following are examples of the three uses of data and how they were applied to organizational change at the University of Oklahoma. Included is a discussion of other management tools that enhanced the change.

The identification of an inefficient procedure was made simple by establishing idle time as a separate category. This revealed a relatively high percentage of idle time, 20.02 percent for front-desk personnel-mostly in the evening. Due to this high percentage of available "free" time, management examined the department organization. As a result, sort-room duties, normally part of stack maintenance responsibilities, were transferred to front-desk personnel. This task was chosen because it could be performed in the front-desk area and permitted personnel to move quickly to the desk to service patrons when heavy traffic required additional help. The problem could have been solved by reducing staffing at the desk, but the ability to serve a sudden influx of patrons would have been hampered.

This solution also proved quite advantageous to the stack maintenance unit. Relieved of sort-room responsibilities, stack maintenance personnel were able to increase their shelf-reading time by more than 100 hours per month. In purely monetary terms, the additional staff time available as a result of the reorganization would have cost the library about $\$ 4,800$ annually. Yet without additional investment of funds, the condition of the stacks improved and service to patrons at the desk did not suffer.

In-house costing can also mark the level of performance from semester to semester. Ideally, costs for charging material should increase only in proportion to salary increases and inflation of maintenance, supplies, etc. If a comparison of costs can be made from repeated sampling studies, increases or decreases in cost can be noted and attributed to changes in procedure, implementation of automation, etc. Of course, the data for such efficiency analysis must exist. Therefore, plans have been made to repeat the sampling procedure at least once a year. This study will then serve as a bench mark to which fu- 
ture findings can be compared. For example, a major change in procedures, such as the reorganization of sort-room duties described earlier, should make a measurable change in the idle-time category and the costs associated with it.

Another method of comparing performance with other activities in a bench mark fashion was done by comparing cost results with discharge accuracy. Returned interlibrary loans are sampled monthly to determine if they have been discharged correctly. This simple quality control measure can assist in monitoring any changes. It can warn of an increase in operator error; even changes arrived at by quantitative means may result in unwanted and unforeseen reductions in quality, and this discharge quality control measure provides a check against such a mishap.

The percentage of time support staff spent at the desk providing backup assistance is one result that can be compared to other research. John Beecher and Francesca Anstine have completed an in-depth study of professional and support staff activity via random work sampling. ${ }^{22} \mathrm{Al}-$ though their study observed overall library staffing, some comparison can be made. Anstine states "Support staff spent more of their time in circulation activities during the fall and spring than in any other area. ${ }^{\prime 23}$ Interpretation of the percentage of support-staff activity at the University of Oklahoma should probably take this into consideration, particularly since the observation period was during the fall. Assuming the Anstine analysis can be applied, it seems reasonable to conclude that our circulation supervisor would spend a lower percentage of time assisting at the desk during the summer. If this conclusion is then correlated with data on discharge accuracy kept in the department, some feel for the "right" percent of time a circulation supervisor should be providing support can be deduced. Specifically, if supervisor support dropped below 10 percent and discharge accuracy was then observed to drop several percentage points, it could be reasonably concluded that more supervisory time was required at the desk to insure discharge consistency. Too much supervi- sor support, though, would not be costeffective due to higher salaries.

\section{DISCUSSION}

Regardless of its origins, organizational change cannot be accomplished without cooperative attitudes among staff or without additional management tools that can help minimize stress. The study itself can often provide a backdrop for change, particularly if all staff are included in planning. For example, the transfer of duties described earlier was enthusiastically initiated by the circulation supervisor because of his integral involvement in the study. Typically, though, when a study reveals needed change, there can be considerable resistance. Coping with resistance to change can be a challenge with several possible solutions, all of which may serve to enhance efficiency of everyday operations. The key to truly effective and practical change based on study data is the use of management data in operations. If use of study data is understood to be a part of the normal course of events, the response of staff to study results will be less defensive.

At the time this study occurred, several management tools that no doubt assisted the transition were in place. Supervisor evaluations have been done for the last two years. This provides an alternative channel for feedback from student workers and probably contributes to the cooperative attitude department-wide. This feedback loop gives students more opportunity to suggest change, based on their viewpoint of work flow and, as a result, changes in procedures take place more readily.

Procedure review was another management tool in effect at the same time. An ongoing revision of procedure manuals has been an important department goal. This review forces staff to scrutinize how a procedure is performed and how it can be pared down to the simplest description. The review is just another situation that makes staff realize that the department is a dynamic and changing entity-again minimizing their resistance to change.

Annual staff evaluations also contributed to the successful reorganization. By 
including the formulation of unit goals in the evaluation process, staff are again forced to examine overall department needs. When such goals are based on sound study data arrived at with staff participation, they are certainly pursued more enthusiastically than goals with seemingly arbitrary or vague origins. The three "tools" described above are just a few of the many possible approaches to management that coordinate well with quantitative measures such as work sampling.

Practicality is another major consideration in implementing change based on quantitative study results. Many of the shortcomings revealed in a work sampling are quite practical in that they often do not require additional funding. Reassignment of duties, changes in procedures, and cancellation or promotion of an underutilized service are simple, everyday solutions that can pay off. Although there is no substitute for a good, observant supervisor, subjectivity can be a problem when intuition or the desire to protect staff positions is a part of the analysis. Quantitative measurement provides an objective yardstick to support supervisory analysis.

The tables generated by SAS on "procedure/time of day" and "procedure/day of the week" are good examples of supervisor analysis that can be enhanced with sampling data. When these tables were analyzed by the circulation supervisor, the student work schedule was revised. Staffing for several periods of the day that had previously been intuitively scheduled as busy periods was reduced when the study indicated such heavy staffing was unnecessary.

Costing data like this may also serve as a rationale for more unusual solutions to stringent budgets. The idea of discouraging circulation and encouraging in-house use is not typical for librarians who usu- ally use circulation statistics as support in funding requests. However, as Richard DeGennaro suggests, ${ }^{24}$ quality rather than quantity is now playing a more important role in such arguments than in the past. As a result, the additional costs of takehome circulation compared to in-house use may prove to be appealing rationale. In addition, the current trend in preservation lends additional weight to this viewpoint. Visualized even further, a circulation desk in a library with a vital public relations campaign encouraging in-house use might conceivably save more dollars by operating part-time.

All this points to a definite need in circulation departments, usually employers of a large number of staff, for repeated sampling and analysis. The large size of most circulation staffs also creates more flexibility when budget constraints force reductions. Under those circumstances, quantitative statistics might be the best resort for a circulation librarian arguing to retain workers. Whether or not such comparisons are significant, library administrators still appreciate the importance of figures on book charge/renewal that show a reduction in cost or a favorable comparison with other institutions. This kind of study provides the information necessary for such comparisons.

In summary, a variety of information was garnered from a simple random observation study. The techniques for this type of study can be easily mastered and are readily accessible in standard texts. ${ }^{25}$ Several comparative studies, cited earlier, already exist in the literature and have assisted in these formulations and analysis. Therefore, a continuing annual study in any circulation department would be relatively simple and could prove most useful in work-flow analysis, efficiency comparisons, and overall examination of department organization.

\section{REFERENCES}

1. William A. Kozumplik, "Time and Motion Study of Library Operations," Special Libraries 58:585-88 (Oct. 1967).

2. Fred J. Heinritz, "Quantitative Management in Libraries," College \& Research Libraries 31:232-38 (July 1970).

3. Glen Densmore and Charles Bourne, A Cost Analysis and Utilization Study of the Stanford University 
Library System, Prepared for Stanford University, Stanford, Califormia (Menlo Park, Calif., Stanford Research Inst., 1965), ED 026 080).

4. John E. Keller, "Program Budgeting and Cost Benefit Analysis in Libraries," College \& Research Libraries 30:156-60 (Mar. 1969).

5. Isobel Jean Mosley, "Cost-Effectiveness Analysis of the Automation of a Circulation System," Journal of Library Automation 10:240-54 (Sept. 1977).

6. Thomas K. Burgess, "A Cost Effectiveness Model for Comparing Various Circulation Systems," Journal of Library Automation 6:75-86 (June 1983).

7. Jerry W. Mansfield, "Using an INS Simulation to Forecast Manpower Needs," Journal of the American Society for Information Science 33:217-21 (July 1982).

8. Daniel R. Bruce, "A Markov Model to Study the Loan Dynamics at a Reserve-Loan Desk in a Lending Library," Library Quarterly 45:161-78 (Apr. 1975).

9. Peter J. Stratton, A Regression Study of Demand, Cost and Pricing Public Circulation Services (Arlington, Va.: ERIC Document Reproduction Service, ED 163 948, June 1978).

10. Paul Little, Bookmobiles and Paperbacks: An Extended Study of the Use of Paperbacks and Elimination of Overdue Fines at the Oklahoma County Libraries, Oklahoma City, Okla. (Oklahoma City, Okla.: Oklahoma County Libraries, Oct. 1976, ED 129 306).

11. Michael K. Buckland, Book Availability and the Library User (New York: Pergamon, 1975); Ava K. Fried and Alice J. Hurlebaus, "A Reevaluation of Circulation Policies," Special Libraries 72:284-89 (July 1981); Ford Jensen, "A Cost Analysis and Usage Study of the Reserved Materials Collection of the University of Arizona Main Library, (Arlington, Va.: ERIC Document Reproduction Service, ED 054 822, Aug. 1971); Paul B. Kantor, Objective Performance Measures for Academic and Research Libraries (Washington, D.C.: Association of Research Libraries, 1984).

12. David F. Kohl, "Circulation Professionals: Management Information Needs and Attitudes," $R Q$ 23:81-87 (Fall 1983).

13. Technical Services Costs in ARL Libraries: Spec Kit 89 (Washington, D.C.: Systems and Procedures Exchange Center, OMS, Association of Research Libraries, 1982); Cost Studies and Fiscal Planning: Spec Kit 52 (Washington D.C.: Systems and Procedures Exchange Center, OMS, Association of Research Libraries, 1979); Determining Indirect Cost Rates in Research Libraries: Spec Kit 34 (Washington, D.C.: Systems and Procedures Exchange Center, OMS, Association of Research Libraries, 1977); Indirect Cost Rates in Research Libraries: Spec Kit 64 (Washington, D.C.: Systems and Procedures Exchange Center, OMS, Association of Research Libraries, 1980).

14. Stella Frank Mosborg, "Measuring Circulation Desk Activities Using a Random Alarm Mechanism," College \& Research Libraries 39:437-44 (Sept. 1980).

15. Edward C. Jestes, "Manual versus Automated Circulation: A Comparison of Operating Costs in a University Library," Journal of Academic Librarianship 6:144-50 (July 1980).

16. Mosborg, "Measuring Circulation Desk Activities,"; J. L. Divilbiss and Phyllis C. Self, "Work Analysis by Random Sampling," Bulletin of the Medical Library Association 66:19-23 (Jan. 1978).

17. Carol C. Spencer, "Random Time Sampling with Self-Observation for Library Cost Studies: Unit Costs of Interlibrary Loans and Photocopies at a Regional Medical Library," Journal of the American Society for Information Science 22:153-60 (May-June 1971); Joel A. Nachlas and Anton R. Pierce, "Determination of Unit Costs for Library Services," College \& Research Libraries 40:240-47 (May 1979); Carol C. Spencer, "Random Time Sampling with Self-Observation for Library Cost Studies: Unit Costs of Reference Questions," Bulletin of the Medical Library Association 68:53-57 (Jan. 1980).

18. John S. Goodell, Libraries and Work Sampling (Littleton, Colo.: Libraries Unlimited; 1975).

19. Ralph M. Barnes, Motion and Time Study: Design and Measurement of Work (New York: Wiley, 1968), p.528.

20. Kohl, p.88.

21. Charles R. McClure, "From Public Library Standards to Development of Statewide Levels of Adequacy," Library Research 2:47-62 (1980).

22. John W. Beecher and others, "Use of Random Alarm Mechanisms for Analyzing Professional and Support Staff Activities in Science Libraries: Part I: Methodology," Library Research 4:137-46 (1982); Francesca A. Anstine and others, "Part II: Data Analysis and Discussion," Library Research $4: 147-61(1982)$.

23. Ibid., p.155.

24. Richard DeGennaro, "Library Statistics and User Satisfaction: No Significant Correlation," Journal of Academic Librarianship 6:95 (May 1980).

25. Richard M. Dougherty and Fred J. Heinritz, Scientific Management of Library Operations, 2d ed. (Metuchen, N.J.: Scarecrow, 1982). 


\section{The world in your hands.}

\section{General}

Yearbook of the United Nations

The principal reference work of the United Nations, providing in single annual volumes, a comprehensive account of the organization's wide-ranging activities since 1946.

Latest issue:

1981 E.84.I.1 (ISBN: $92-2-100038-6$ ) $\$ 75.00$

\section{Everyone's United Nations}

Official textbook which contains a definitive history of the Organization from 1946 to date.

Latest issue: 10 th ed

E.85.1.16 (ISBN: 92-1-100273-7) \$14.95 (cloth) E.85.I.16 (ISBN: $92-1-100274-5) \$ 9.95$ (paper)

\section{Directory of United Nations Databases} and Information Systems

A repertoire of over 600 information databases in $36 \mathrm{UN}$ affiliated organizations. It enables one to see what information and services are available in the United Nations family as a whole and how to obtain detailed information from particular organizations. GV.E.84.0.5 (ISBN: $92-9048-295-8) \$ 35.00$

\section{Assumptions and Perceptions in}

Disarmament

Provides a comprehensive and sincere survey on Soviet and American assumptions and perceptions. It offers an indispensable contribution for understanding the dynamics of Soviet and American armaments and disarmament.

GV.E.84.0.4 (ISBN: 92-9045-006-1) $\$ 14.00$

\section{Racism and its Elimination}

by Sir Rupert John

Racism is learned and can, therefore, be unlearned. It is also argued that racial

discrimination undermines human rights and threatens the peace and security of our world. E.81.XV.ST/18 (ISBN: 92-1-157057-3) $\$ 15.00$

\section{Fertility and Family}

International Conference on Population 1984.

Proceedings of the Expert Group on Fertility and Family.

E.84.XIII.7 (ISBN: 92-1-151099-6) $\$ 41.00$

\section{United Nations Action in the Field of Human Rights}

Reviews United Nations activities in the field of Human Rights from 1945 to 1977 . It sets forth the measures taken by the Organization and also describes administrative procedures.

E.79.XIV.6 (ISBN: $92-1-154022-4$ ) $\$ 24.00$
UNBIS (United Nations Bibliographic Information System) Thesaurus Trilingual list of terms in English, French and Spanish used in indexing and cataloguing of documents and other materials relevant to United Nations programmes and activities for the UNBIS system. 2nd edition.

E.85.1.20 (ISBN: 92-1-100279-6) $\$ 25.00$

Report on the World Social Situation Biennial since 1961

Latest issue: 1984 E.85.IV.2 (ISBN:

$92-1-130097-5) \$ 17.50$

\section{Reference}

\section{Handbook of Industrial Statistics}

This analysis provides comprehensive coverage of industrial statistics that will be of interest to researchers in a variety of fields. It examines important structural trends in 70 developing and developed countries, including: changes in the pattern of apparent growth in all industrial branches, the changing composition of output in all the manufacturing sector and the export performance of key industries.

E.82.II.B.2 (ISBN: $92-1-106117-2) \$ 22.00$

\section{Statistical Yearbook for Asia and the} Pacific

Contains a wealth of statistics covering population, manpower, national accounts, agriculture, forestry and fishing, industry, energy supplies, consumption, transport and communications, internal and external trade, wages and banking. Bilingual English/French.

Latest issue: 1982

E/F.84.II.F. 8 (ISBN: $92-1-019003-3) \$ 52.00$

\section{Statistical Yearbook for Iatin America}

This survey is an overall appraisal of Latin American economy and its place in the world economy. Balance of payments, growth, prices, trade, employment and labour productivity and external finance are surveved in utmost detail. Latest issue: 19832 vols.

E.84.II.G.2 (ISBN: 92-1-021003-4) $\$ 40.00$

Yearbook of International Commodity Statistics

First issue: 1984

E.84.II.D. 22 (ISBN: $92-1-112180-9) \$ 45.00$
The United Nations Disarmament Yearbook

Issued since 1976.

Topics include special sessions of the General Assembly devoted to disarmament, nuclear arms limitations (including SALT II. Test-Ban LAEA Safeguards), prohibition of chemical, biological and radiological weapons and reduction military budgets.

Latest issue: Vol. VII 1982

E.83.IX.7 (ISBN: $92-1-142026-1) \$ 22.00$

\section{Demographic Yearbook}

Covers data on population for more than 250 countries and areas. Annual since 1949.

Latest issue: 1983

E/F. 84.XVIL.1 (ISBN: 92-1-051030-5) $\$ 90.00$

(cloth)

(ISBN: 92-1-051029-1) $\$ 80.00$ (paper)

\section{Statistical Yearbook}

Provides a wealth of data for more than 280 countries and territories on economic and social subjects such as population, agriculture, trade, national income and many others. Annual since 1949

Latest issue: 1982

E/F. 84.XVIL.1 (ISBN: 92-1-061100-4) \$70.00 (cloth)

E/F 84 XVILI (ISBN: 92-1-061101-2) $\$ 60.00$ (paper)

Yearbook of International Trade Statistics

Annual since 1950.

Latest issue: 1982 ( 2 vols.)

E/F.84.XVII.6 (ISBN: 92-1-061002-4) $\$ 80.00$

\section{National Accounts Statistics}

Annual since 1957

Latest issue: 1982 ( 4 vols.)

E. 85 XVII. $3 \$ 85.00$

E.85XVII. $4 \$ 45.00$

E. 85 XVII. $5 \$ 35.00$

E.85.XVII.6 (forthcoming)

\section{Yearbook of Construction Statistics} Annual since 1974 .

This yearbook provides international statistics on dwelling construction which permits an outlook on the relevant industries.

Latest issue covers 1975-1982

E. 84.XVII.9 (ISBN: 92-1-161049-4) $\$ 35.00$

\section{Industrial Statistics Yearbook}

Former title: Yearbook of Industrial Statistics Annual since 1950.

Latest issue: 1982 ( 2 vols.)

E.84.XVII.7 $\$ 50.00$

E.84.XVII.8 $\$ 50.00 \$ 95.00$ (set) 


\section{Nations Publications}

Law

\section{Law of the Sea}

The Convention on the Law of the Sea creates a new record in legal history covering every aspect of the uses and resources of the sea.

E.83.V.5 (ISBN: 92-1-133243-5) \$12.95

Yearbook of the International Court of Justice

Published since 1946

The Yearbook discusses the cases before the Court, usually pertaining to territorial rights, law of the sea and treaty interpretation but a wide range of topics have been covered over the years. Latest issues: 1983-84 (No. 38) ICJ No. 502 $\$ 10.00$

\section{Reports of International Arbitral} Awards

Latest issue: vol. 18

E/F.80.V.7 (ISBN: 92-1033-009-9) $\$ 33.00$

\section{United Nations Juridical Yearbook} Included in the volume are legislative texts and treaty provisions concerning the legal status of the United Nations and related bodies, and a general review of their legal activities.

Latest issue: 198

E.84.V.1 (ISBN: $92-1-133332-6) \$ 25.00$

\section{United Nations Commission on} International Trade Law Yearbook Annual issued since 1968 .

Included are studies and reports on international trade contracts, international payments, international commercial arbitration and conciliation, the new international economic order transport law and activities of other organizations. Latest issue: 1983 E.85.V.3 $\$ 41.00$

\section{Yearbook of the International Law \\ Commission}

Issued since 1949

Subjects dealt with include arbitral procedures, diplomatic immunities, law of the sea, nationality, law of treaties and rights and duties of States. Latest issue: 1983

vol. I E.84.V.6 $\$ 33.00$

vol. II pt. 1 E.84.V.7 (ISBN: 92-1-133262-1)

$\$ 23.00$

vol. II pt. 2 E.84.V.7 (ISBN: 92-1-133331-8)

$\$ 12.50$

\section{Energy/Environment}

\section{Energy in the Eighties}

Highlights of the Meeting of the Ad Hoc Group of Energy and Petroleum Experts.

E. 83.II.A.16 (ISBN: 92-1-104138-4) \$16.50

Main Features and Trends in Petroleum and Mining Agreements

Prepared by United Nations Centre on

Transnational Corporations

E.83.II.A.9 (ISBN: $92-1-104057-4) \$ 13.50$

A Guide to Ocean Thermal Energy

Conversion for Developing Countries E.83.II.A.21 (ISBN: $92-1-104148-1) \$ 9.50$

\section{Energy Transition in the ECE Region} E.83.II.E.21 (ISBN: 92-1-116305-6) $\$ 16.50$

\section{Energy Statistics Yearbook}

Provides a global framework of comparable data on trends and developments in the supply of all forms of energy. Essential to study the outlook in the supply and demand of energy. Hardcover. latest issue: 1983 E/F.85.XVII.9 $\$ 45.00$

\section{Airborne Sulphur Pollution}

This thought-provoking report was prepared within the framework of the Convention on Long-range Transboundary Air Pollution. It assesses air pollution effects on the environment, evaluates the technical efficiency and costs for controlling pollutant emissions and analyses costs and benefits of alternative emission control programmes. E.84.II.E. 8 (ISBN: $92-1-116307-2$ ) $\$ 19.00$

\section{Business/Economics}

The studies presented in both of the following publications are compulsory reading for industrial project planners who seek to successfully negotiate with government planners of developing countries. These titles have been widely adopted as textbooks at economics education centres.

Will a project contribute towards increasing emplovment and higher buving power for the population? What would be the impact on distribution of income and quality of living? Guidelines for Project Evaluation proposes methods to evaluate projects in order to provide the answers, and should be used in conjunction with the Manual for the Preparation of Industrial Feasibility Studies.

Guidelines for Project Evaluation. E.72.II.B.11 (ISBN: 92-1-106084-2) $\$ 20.00$

Manual for the Preparation of Industrial Feasibility Studies. E.78.II.B.5 (ISBN: 92-1-106109-1) $\$ 9.00$

\section{World Economic Survey}

Provides an overview of salient developments in the world economy. Attention is drawn to changes in international policies needed to improve the pace of development in developing countries. Annual since 1948.

Latest issue: 1985

E.85.II.C.1 (ISBN: 92-1-109107-1) \$14.50

Macrothesaurus for Information

Processing in the Field of Economic and Social Development

This third edition of the Macrothesaurus has been produced in cooperation between the $\mathrm{UN}$ and $\mathrm{OECD}$ and is a trilingual English/French/Spanish multidisciplinary vocabulary for the indexing. classification, retrieval and exchange of information on economic and social development. E.85.1.15 (ISBN: $92-1-100272-9$ ) $\$ 25.00$

Transnational Corporations and International Trade: Selected Issues A Technical Paper. E.85.II.A. $4 \$ 11.00$

To order publications, by title and sales number. contact your wholesaler or order direct. For more information write for our complete 1985 catalog at the address below.

Publisher's ISBN prefix: (92-1)

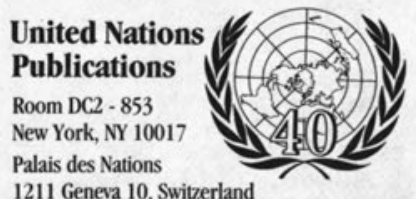




\section{"I used to shudder when patrons requested information on a proceedings paper."}

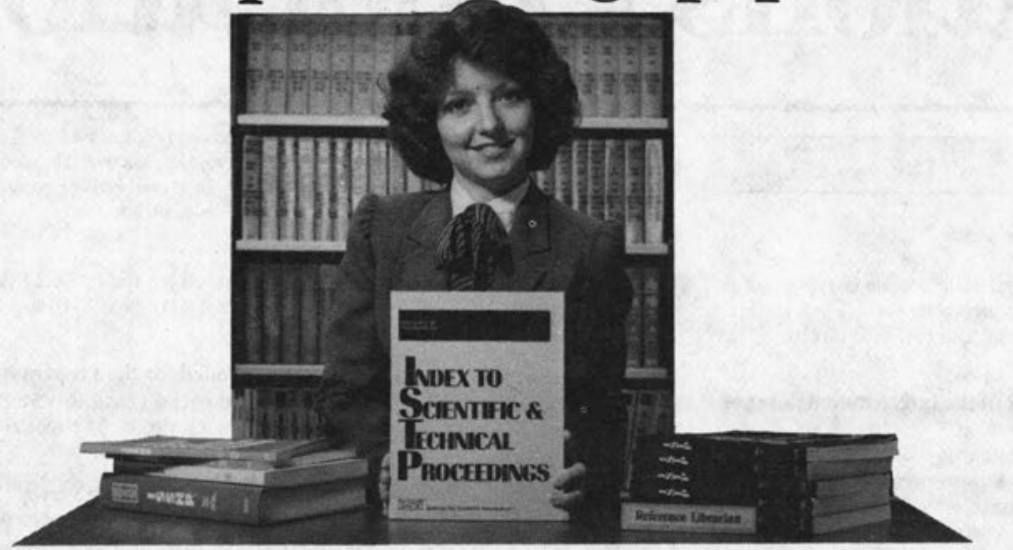

\section{"Now I Reach for ISTP ${ }^{\circ}$ and ISSHP."}

Tow you too can get easy access to indi1 vidual papers published in conference proceedings .... with the Index to Scientific \& Technical Proceedings ${ }^{\circledR}$ and the Index to Social Sciences \& Humanities Proceedings ${ }^{*}$. Each year, ISTP indexes over 120,000 individual papers, and ISSHP nearly 20,000 . Over $70 \%$ of this material is not indexed in the Science Citation Index ${ }^{8}$ or in the Social Sciences Citation Index ${ }^{3}$.

Since the proceedings literature is generally the first place where early research results appear, you'll find ISTP and ISSHP useful for bibliographic verification, retrospective searches - even for current awareness! Any of six access points quickly lead you to complete descriptions of proceedings and the individual papers presented in them. And the main entries display proceedings in a contents-page format-ideal for easy scanning. Each entry provides the full bibliographic information you need.

Why not make these valuable indexes part of your library's reference collection? A yearly subscription to ISTP is $\$ 725$, and to ISSHP is $\$ 525$.

For more information-and to receive your FREE sample issue of ISTP or ISSHP-just fill out and mail the coupon below. Or call us toll-free 800-523-1850, extension 1371.

Remember, no literature search is complete without checking the proceedings in ISTP or ISSHP.

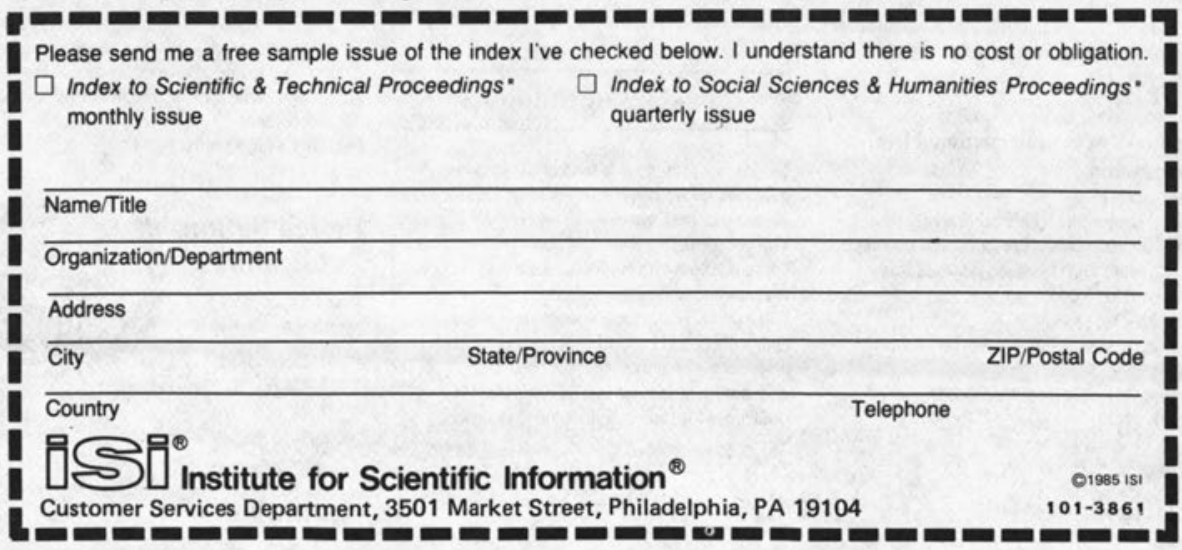

